\title{
Apocrine Carcinoma Developing in a Naevus Sebaceous of Scalp
}

\author{
Paudel U, ${ }^{1}$ Jha $A,{ }^{1}$ Pokhrel DB, ${ }^{1}$ Gurung $D,{ }^{2}$ Parajuli $S,{ }^{1}$ Pant $A^{1}$
}

\author{
${ }^{1}$ Department of Dermatology \\ ${ }^{2}$ Department of Pathology \\ Tribhuvan University Teaching Hospital, Maharajgunj \\ Medical campus, Kathmandu, Nepal \\ ${ }^{3}$ Department of Dermatology
}

Venereology, Leprology, Consultant, DI Skin Hospital and research centre, Kathmandu, Nepal

\section{Corresponding Author}

Upama Paudel

Department of Dermatology

Tribhuvan University Teaching Hospital, Maharajgunj Medical campus, Kathmandu, Nepal

Email:upama_ups@yahoo.com

\section{Citation}

Paudel U, Jha A, Pokhrel DB, Gurung D, Parajuli $S$, Pant A. Apocrine Carcinoma Developing in a Naevus Sebaceous of Scalp. Kathmandu Univ Med J 2012;38(2):103-105..

\begin{abstract}
Apocrine skin carcinoma is an aggressive cutaneous tumour. We report a case of apocrine carcinoma developing in a naevus sebaceous of scalp in a 45 years old male. Malignant transformation of Naevus sebaceous is a rare complication usually found in elderly patients. Most of these tumours are basal cell carcinoma or squamous cell carcinoma. Only few cases of apocrine carcinoma on naevus sebaceous have been previously reported. This report highlights the potential of naevus sebaceous for malignant transformation.
\end{abstract}

\section{KEY WORDS}

Apocrine, Basal cell carcinoma, carcinoma, hamartoma, nevus, Sebaceous of Jadassohn, skin.

\section{INTRODUCTION}

Naevus sebaceus of Jadassohn (NSJ) is a hamartoma that combines epidermal, follicular, sebaceous, and apocrine gland abnormalities with predominant sebaceous component. Varieties of appendageal tumours, sometimes multiple may develop within a sebaceous naevi. The most common reported are syringocystadenomapapilliferum and trichoblastoma. ${ }^{1}$ Malignant transformation of naevus sebaceous is a rare complication usually found in elderly. Locally invasive and malignant tumours include keratoacanthoma, proliferating trichilemmal cyst, basal cell carcinoma, eccrine and squamous cell carcinoma and malignant melanoma. ${ }^{2-7}$ Only few cases of apocrine skin carcinoma developing in NSJ (around only eight), have been previously reported..$^{8,9}$ Apocrine skin carcinoma is a rare tumour. It usually occurs in areas of skin bearing apocrine gland in order of frequency, in the axilla, external ear, eyelid and anogenital region. When it occurs in scalp, it is always secondary to naevus sebaceous of Jadassohn. This report recalls the potential of NSJ for malignant degeneration.

\section{CASE REPORT}

A 45 years old man presented to out patient skin department of Tribhuvan University Teaching Hospital with complaints of palpable, asymptomatic, rough plaque on the left mastoid region since childhood. The lesion gradually increased in size and was initially associated with mild itching and later followed by exudation and pain. A rapidly progressive nodule developed in the middle of the plaque over last four months and was associated with pain and purulent discharge. There was no history weight loss or loss of appetite. Reviews of systemic symptoms were normal. On examination, there was a $4 \times 7 \mathrm{~cm}$ size rough 


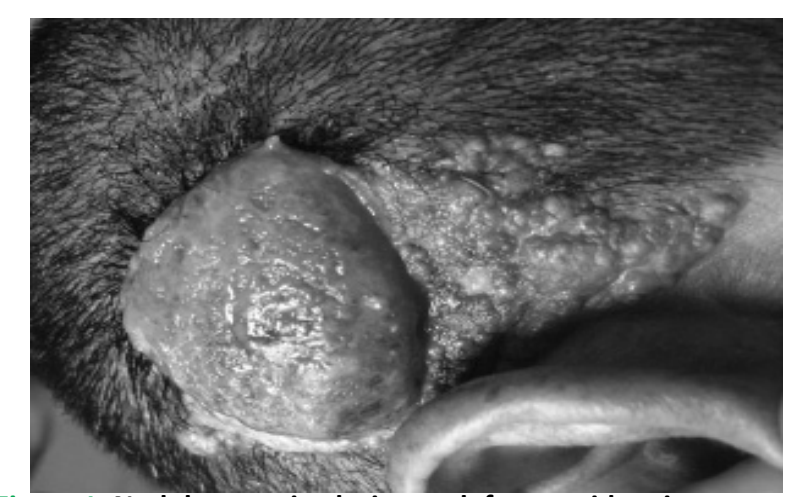

Figure 1. Noduloucerative lesion on left mastoid region.

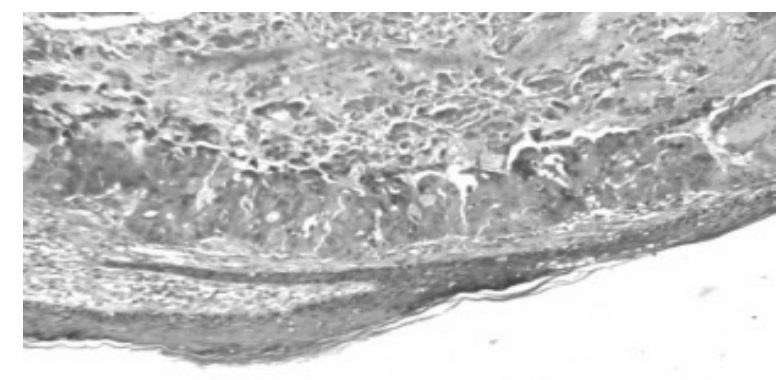

Figure 3. Apocrine tumour cells below the epidermis.

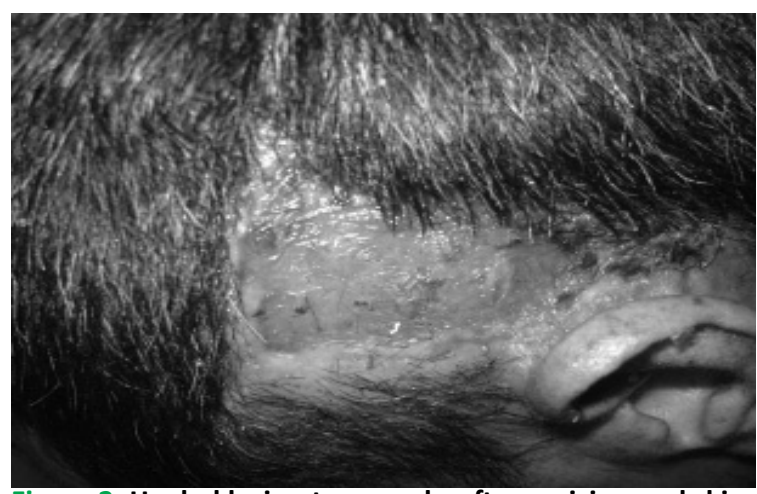

Figure 2. Healed lesion two weeks after excision and skin grafting.

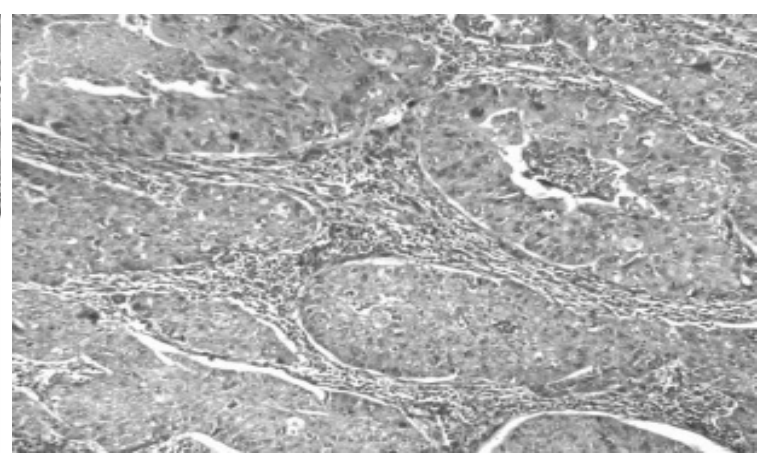

Figure 4. Apocrine tumour cells.

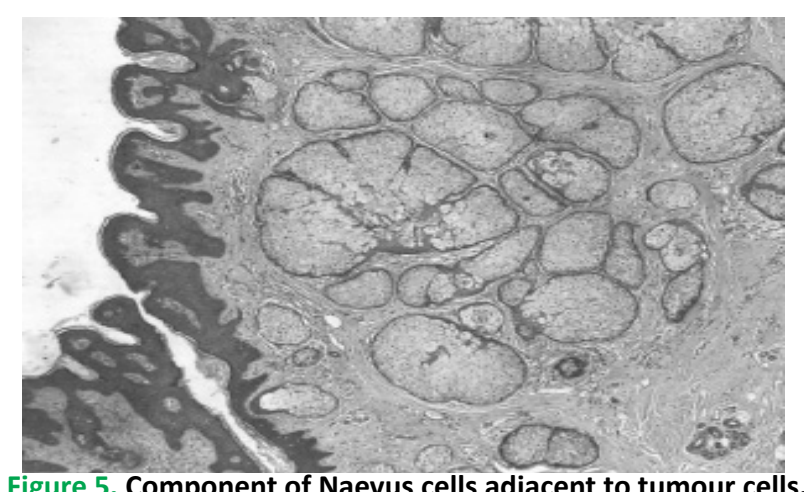

Figure 5. Component of Naevus cells adjacent to tumour cells.

hairless velvety plaque on left mastoid region. A $2 \times 2 \mathrm{~cm}$ size erythematous nodule covered with yellowish slough was present in the centre of the lesion; this was tender to touch and on removal of slough revealed a granulation tissue like beefy red nodule(fig 1). There was no induration and the plaque was mobile. In addition two discrete, mobile and non tender posterior cervical lymph nodes measuring $1 \mathrm{X} 1$ $\mathrm{cm}$ and $1 \times 2 \mathrm{~cm}$ were palpable. Systemic examination was normal. On investigation, complete blood count, renal function tests, liver function tests were normal. $X$ ray chest showed fibrotic bands on right side with tracheal shift towards right. CT chest showed no features of malignancy but suggestive of healed tuberulosis. $X$ ray skull was normal. USG abdomen and pelvis was normal. FNAC of lymph node showed reactive lymphadenitis.

Histopathological examination of incisional biopsy from the nodule in the left mastoid region showed infiltrative atypical cells with prominent and crowded tubular and ductal structures involving full thickness of the dermis. Tumor cells showed abundant to moderate eosinophilic cytoplasm and pleomorphic vesicular to hyperchromatic nuclei with prominent nucleoli. Occasional mitotic figures were also noted. There were inflammatory cell infiltrates and hemorrhage in the stroma. Ulcerations were also noted without necrosis. The features were suggestive of apocrine carcinoma.

The lesion was excised in toto and sent for histopathology. A split skin graft was placed. The lesion healed within two weeks time without any complications (fig 2). Excisional biopsy revealed ulcerated epidermis with underlying dermal tumor (fig 3). Tumor cells were seen arranged in variable patterns including papillae, mucin containing tubular structures, microcystic patterns and ducts. There were cystic structures containing comedo type necrosis. Tumor cells were round to polygonal with round to oval irregular vesicular nuclei with cytoplasmic clearing (fig 4). Some of these cells showed eosinophilic cytoplasm. There was moderate to marked degree of nuclear pleomorphism. Focally there were areas of squamous differentiation. No lymphovascular or perineural invasion seen. Mitosis was frequent up to $4 / \mathrm{hpf}$ in mitotically active areas. All surgical resected margins were free of tumour. Sections also showed a component of nevus sebaceous adjacent to tumor (fig 5). It was characterized by lobules of sebaceous 
glands lacking well formed hair follicles; however, a few primitive hair follicles were seen. Dilated apocrine ducts were also seen in mid dermis adjacent to tumor. With these findings a diagnosis of apocrine carcinoma arising within naevus sebaceous was made.

\section{DISCUSSION}

Sebaceous naevi occur in about $0.3 \%$ of all neonates. ${ }^{10,11}$ In adulthood various appendage tumors frequently develop in about $14 \%$ of NSJ. ${ }^{12,13}$ But these are mostly benign. Less than $1 \%$ of NSJ are complicated by malignant tumours according to recent retrospective studies. ${ }^{1,14,15}$ Basal cell carcinoma has been described as the most common neoplasm developing in association with NSJ. Its frequency in reported series varies, mainly due to the differences in interpreting what really represents basal cell carcinoma. Many of the basal cell carcinomas developing in nevus sebaceus do not confirm exactly to the standard neoplasms arising independently from this hamartoma. ${ }^{15}$ In the opinion of Steffen and Ackerman they are often examples of trichoblastoma. ${ }^{16}$ Several types of malignant adnexal neoplasms, including cutaneous apocrine carcinoma are also described to occur but the numbers of the cases are limited.

Cutaneous apocrine carcinoma is a rare malignancy

\section{REFERENCES}

1. Jaqueti G, Requena L, Sanchez yus E. Trichoblastoma is the most common neoplasm developed in nevus sebaceous of Jadassohn: a clinicopathologic study of a series of 155 cases. Am J Dermatopathol. 2000 Apr; 22(2): 108-18.

2. Ujiie $\mathrm{H}$, Kato $\mathrm{N}$, Natsuga $\mathrm{K}$, Tomita $\mathrm{Y}$. Keratoacanthoma developing on naevus sebaceous in a child. J Am Acad Dermatol. 2007; 56(2suppl.): S57-8.

3. Rahbari $\mathrm{H}$, Mehregan A. Development of proliferating trichilemmal cyst in an organoid nevus. J Am Acad Dermatol. 1986; 14: 123-6.

4. Miller CJ, loffreda MD, Billingsley EM. Sebaceous carcinoma, basal cell carcinoma, trichoadenoma, trichoblastoma, and syringocystadenoma papilliferum arising within a nevus sebaceus. Dermatol Surg. 2004; 30: $1546-9$.

5. Ball EA, Hussain M, Moss AL. Squamous cell carcinoma and basal cell carcinoma arising in a naevus sebaceous of Jadassohn: case report and literature review. Clin Exp Dermatol. 2005; 30: 259-6.

6. Tarkhan II, Domingo J. Metastasizing eccrine porocarcinoma developing in a sebaceous nevus of Jadassohn: report of a case. Arch Dermatol. 1985; 121: 413-5.

7. Abe $S$, Yamamoto $Y$, Uno $S$. Malignant melanoma arising in a sebaceous nevus of the scalp. Br J Plast Surg. 2003; 56: 171-3.

8. Dalle S, Skowron F, Balme B, Perrot H. Apocrine carcinoma developed in nevus sebaceus of Jadassohn. Eur J Dermatol. 2003; 13: 487-9.

9. K. Tanese, A Wakabayashi, T Suzuki, S Miyakawa. Immunoexpression of human epidermal growth factor receptor- 2 in apocrine carcinoma arising in naevus sebaceous, case report. JEADV. 2010;24:356-369. histologically defined as an adenocarcinoma forming nests of glandular lumina with decapitation secretion of lining neoplastic cells. Tumour cells are positive for mucin stain as demonstrated by Periodic acid Schiff stain with and without diastase and are positive on immunostaining for GCDFP-15. ${ }^{17}$ It develops in areas where apocrine glands are numerous, such as axilla and the anogenital region. The aetiology of cutaneous apocrine carcinoma (CAC) is not known, but association with naevus sebaceous has been suggested and eight cases are reported so far. ${ }^{8,18}$ As naevus sebaceous develops into anomalous dilated apocrine glands in the adulthood, it is speculated that some oncogenic events might occur in those hamartomatous apocrine glands, giving rise to CAC. However, molecular event occurring in this tumour is not precisely understood.

Malignant transformation within NSJ during childhood or teen-age is exceptional. Recent retrospective studies which analyzed the histologic findings on NSJ removed during childhood, adolescence or in young adults found little malignant transformation. However, in the largest study, malignant tumors were found on $1.2 \%$ of the 19 to 40 -years old age group and up to $2.1 \%$ when patients were older than 40 years. ${ }^{14}$ We believe that the development of aggressive tumors on NSJ in adults such as apocrine carcinoma in our case, justifies the preventive surgical excision of the lesions and a prolonged surveillance of these patients.

10. Alper J, Holmes LB, Mihm MC. Birthmarks with serious medica significance: nevocellular nevi, sebaceous nevi, and multiple café-aulait spots. J Pediatr. 1979; 95: 696-700.

11. Tsai F-J, Tsai C-H. Birthmarks and congenital skin lesions in Chinese newborns. J Formos Med Assoc. 1993; 92: 838-41.

12. Yoon DH, Jang IG, KimTY, Kim HO,Kim CW. Syringo cystadenoma papilliferum, basal cell carcinoma and trichilemmoma arising from nevus sebaceous of Jadassohn. ActaDermVenereol. 1997; 77:242-3.

13. Rosenblum GA. Nevus sebaceous, syringocystadenoma papilliferum, and basal cell epithelioma. J Dermatol Surg Oncol. 1985;11:1018-20.

14. Cribier B, Scrivener $Y$, Grosshans E. Tumors arising in nevus sebaceous :a study of 596 cases. J Am Acad Dermatol. 2000;42:263-8.

15. Alessi E, Wong SN, Advani HH, Ackerman AB. Nevus sebaceus is associated with unusual neoplasms. An atlas. Am J Dermatopathol. 1988; 10:116-27.

16. Steffen C, Ackerman AB. Nevus sebaceus. In: Neoplasms with Sebaceous Differentiation. Philadelphia, PA: Lea \& Febiger; 1994:89144.

17. Paties C, Taccagni GL, Papotti M. Apocrine carcinoma of the skin :a clinicopathologic, immunocytochemical,and ultrastructural study. Cancer. 1993; 71: 375 -381.

18. Robson A, Lazar AJ, Ben Nagi J. Primary cutaneous apocrine carcinoma :a clinico-pathologicanalysis of 24 cases. Am J Surg Pathol. 2008; 32:682-960 